\title{
The Effect of Interpersonal Relationships and Role Ambiguity on Job Satisfaction and Its Impact Toward Employees' Intention to Leave in Event Organizer Services Provider in Medan
}

\author{
Indayana Dalimunthe \\ Department of Management \\ Faculty of Economic and Business \\ Universitas Sumatera Utara, USU \\ Medan, Indonesia \\ Indayanad@gmail.com
}

\author{
Yeni Absah \\ Department of Management \\ Faculty of Economic and Business \\ Universitas Sumatera Utara, USU \\ Medan, Indonesia
}

\author{
Sitti Raha Agoes Salim \\ Department of Management \\ Faculty of Economic and Business \\ Universitas Sumatera Utara, USU \\ Medan, Indonesia
}

\begin{abstract}
Event organizer has been growing fast in modern society as an answer for people's need to hold events for them without managing the event themselves. Event organizer enabled people to hold events without properly plan, organize, act, and control the events. As result, there is a high demand for event organizer services. Many events nowadays were hold using event organizer services. Unfortunately, the employees' turnover ratio within event organizer was high. This study aimed to evaluate antecedents of employees' intention to leave. This study evaluated a relationship between interpersonal relationship and role ambiguity with employees' job satisfaction and its impact toward intention to leave. A number of 63 employees from seven event organizations in Medan were participated in this study. Data were gathered by using self-administered questionnaires. The data were analyzed using structural equation model by using SmartPLS. This study showed that interpersonal relationship had a positive and significant effect toward job satisfaction event organizer's employees. The presence of role ambiguity had a negative and significant effect toward job satisfaction. As for employees' intention to leave, interpersonal relationship and role ambiguity may reduce employees' intention but its effect was not significant. The evidence showed that job satisfaction significantly affect the intention to leave. Role ambiguity affect employees' intention to leave positively whereas job satisfaction negatively affect them. Job satisfaction also acted as significant mediating variable for interpersonal relationship and role ambiguity to affect employees' turnover intention. Thus, in order to reduce employees' turnover intention, management should pay more attention toward their employees' job satisfaction which in this research become determinant factor of intention to leave.
\end{abstract}

Keywords - Turnover; Intention to Leave; Job Satisfaction; Role Ambiguity; Interpersonal Relationship

\section{BACKGROUND}

Changes in taste and lifestyle very quickly requires every company to be able to continue to adapt and innovate in creating new types of businesses that can meet the needs and desires of the consumer. The industry of event organizing service or better known as event organizer (EO) is one of the industries that emerged as a result of changes to the lifestyle and the way of thinking of contemporary society. Kasali defined Event organizer as a business that implements the concept of management continuously and consistently in exploring the entertainment world as deeply as built from a team that records every single detail from the process of choosing the event, packing the event, fulfilling payment, taking care of the permit, ensuring the security of the implementation, recording the fluctuation of desire market, and prepare the technology and marketing, until the event report (evaluation report) or evaluation.

The growth of the EO services in Medan city is quite high, as evidenced by the number of new EO companies standing in Medan city. The growth is not separated from the high interest of the community using the EO services in organizing the desired event. The work practice of EO consists of a series of systematic mechanisms and requires perseverance, sincerity and teamwork to produce a successful event. To achieve these, the employees are often faced with the targets, the scheduling, the pressure, and the deadlines to ensure that everything that is needed is running as it should be. Such working conditions can create the work pressures. The uncontrolled work pressure will affect the employee job satisfaction and ultimately impact on the desire to leave the company. The intention to move (intention to leave).

Intention to leave must be addressed as an important phenomenon in organizational life from an individual and social point of view, given that the level of the employee turnover intentions had significant impacts for the company and the individual concerned [1]. Almost all organizations, including the EO companies experienced employee turnover. To see the phenomenon of turnover in the EO companies conducted pre-survey. The pre-survey results showed that the EO companies in Medan city experienced a fairly high turnover rate. The various factors causing the turnover into things that must be considered the EO companies in order to reduce the turnover rate that occurred. One factor that was very often associated with the intention to leave was the factor of job satisfaction.

Job satisfaction becomes the fundamental thing to be considered because it is able to influence one's thinking to get out of the workplace and try to find another better job than the previous workplace. The employees with high job satisfaction 
will feel good about their work and not looking for another job. Conversely, the unsatisfied employees tend to have thoughts of getting out, and evaluate other work alternatives and are willing to quit expecting to find more satisfying work [2].

The pre-survey results revealed that the factors that give the greatest influence on job satisfaction are interpersonal relationships. While the lowest value in providing job satisfaction was the job itself. Seeing the characteristics of the EO companies turned out the role ambiguity was one of causes of the emergence of job dissatisfaction.

The phenomenon is the basis for the necessity of this research is done, namely by define the factors that can lead to the intention to leave the employees of the EO companies. The purpose of this research is to examine and analyze whether there is influence of interpersonal relationship and role ambiguity to job satisfaction and its impact on intention to leave the employees of the event organizer companies in Medan city.

\section{LITERATURE REVIEW}

\section{A. Intention to Leave}

The problem of the employee turnover is a form of realization of a desire to leave the company (intention to leave) which is manifested in exit action from the company. Intention to leave is a desire someone to get out of the company. Intention to leave the employees refers to the wishes of employees regarding the continuity of its relationship with the company but has not yet been realized in the exact action of leaving the organization [3]. While the term "turnover" describes the end result of the exact action or behavior taken by the employees in the form of exit from the company, thus causing a decrease in the number of the employees in a certain period.

Another opinion expressed that the desire to move or turnover intention is a tendency of attitudes or levels which an employee has the possibility to leave the organization or voluntarily resign from his job [4]. In line with the theory Grant et al disclosed, Sulistiyawati described the Intention to leave as the tendency or intention of the employees to stop working from their work voluntarily according to their own choice. In general it can be said that the intention to leave is a tendency of the employees to quit from their current job with a variety of reasons owned.

\section{B. the Interpersonal Relationsip at Work}

Basically, the humans live as the individual creatures as well as the social. The humans intend to establish the relationships with other individuals and need each other, this relationship is often referred to as interpersonal relationships. Humans as social beings need the friendship and mutual respect so that they will not be happy to be left alone, for that they will have a good relationship with their colleagues [5].

In organizing activities, interpersonal relationships are the interactions between a person and others in work situations and within the organization as a motivation to cooperate productively [6]. so achieved the economic, psychological and social satisfaction. The EO's work relies heavily on the good interpersonal relationships to the colleagues and to the superiors, in order to build solid and mutually supportive teamwork.

\section{The Role Ambiguity in the event Organizer Environment}

The role ambiguity has been defined by some expert with different sentences but with similarities of meaning and the point. The role ambiguity occurs when the individuals are not clarified about the tasks of their work or are more generally said to "not know what to do" [7]. Role ambiguity arose when the role expectation was not clearly understood and one was not sure what he was doing [8].

The role ambiguity is the degree to which less obvious information about expectations is related to roles, methods to fulfill the role expectations, or the consequences of the role performances. In other words, the role uncertainty is the difference between the number of people and the amount of information that they need to carry out their role adequately. A person can be said to be in the role ambiguity when shows the following characteristics: it was not clear exactly what the purpose of the role he was playing; it was unclear to who was responsible and who reports to him; not enough authority to carry out its responsibilities; not fully understand what was expected of him; and did not understand the true role of the work in order to achieve the overall goal [9].

\section{The Job Satisfaction and the Intention to Leave}

Job satisfaction is considered to be one of the determinants of a person's desire to leave the company, an employee who is satisfied with his work will have a positive impact, one of which is the decrease in intention to leave. The job satisfaction is the result of employees' perceptions of how well their work provides what is considered important.

The job satisfaction as an individual's general attitude toward his job. The difference between the amount of rewards a worker earned and the amount they believe they should receive. Another definition was put forward by Martoyo that stated that the job satisfaction is an emotional state of employees that occured or did not occur the intersection between the value of the repayment of the employee and the company or organization with the level of the value of the repayment that the employee wants [10].

\section{THE CONCEPT FRAMEWORK AND HYPOTHESES}

The main focus of this research is to explain the effects of the interpersonal relationships and the role ambiguity on the job satisfaction and its impact on the employee' intention to leave which work in the event organizer company. The interpersonal relationships and the role ambiguity are considered to affect the job satisfaction and intention to leave the company. Although some researchers have previously examined using the same variable, but the research that makes the event organizer company as the object of the research is still very limited. During this time, the research on the event organizer service companies is still very little and need to be studied more deeply by the further researchers. 
There are many factors that affect of the job satisfaction, one of the factors that allegedly affect is the interpersonal communication. With the good interpersonal communication will be able to improve the job satisfaction. There are two possibilities that cause a person's job dissatisfaction, the first because the person does not get the information which he needs about his job and the second because of the relationship with colleagues who are less good [11].

Good interpersonal relationships within the company can help employees to improve job satisfaction [12]. In another research, Lim and Jeniffer entitled "Impact of Coworkers' Relationship on Organizational Commitment and Intervening effect of Job Satisfaction" revealed that When the relationship of the leadership and the employees as well as interaction between the employees running well, then the higher the level of job satisfaction [13]. This research is in line with the results of the research of Lee, et al, which suggested that a more harmonious co-worker relationship between hotel employees and higher levels of satisfaction about the work environment has a positive and significant effect on job satisfaction [14].

The next variable that is also considered capable of giving influence to job satisfaction is the role ambiguity factor. The role ambiguity is one of the factors that should be minimized in the company. In some researches, the role ambiguity proved to have an effect on the job satisfaction, such as the research undertaken by Ketaren who argued that the role ambiguity has a significant effect on employee's job satisfaction [15]. Although some reseaches have found that the role ambiguity has a significant effect on the job satisfaction, but there are also research findings that found the different results, as in Rohmawati's research result which stated that the role ambiguity has no effect on the job satisfaction [16].

Meanwhile, for direct effect of the interpersonal relationship to turnover has also been done by Tew and Michele in the Impact Coworker Support on Employee Turnover in the Hospitality Industry, where the results found that the interpersonal relationships directly affect on the intention to leave, retention rate, and work attachment [17]. Mossholder et al, and Regts et al also suggested the similar results that an employee's relationships in his or her work significantly impact the employees' decisions about staying with their organizations or finding new jobs elsewhere $[18,19]$.

The role ambiguity is directly considered to be able to influence the employees' intention to leave as in Cahyono, researches where they found that the vagueness of the roles experienced by employees has a significant effect on the willingness to move to work [20]. However, in some other researches, those who found that the role ambiguity had no significant effect on the employees intentions to leave [21,22]

Job satisfaction is believed to be one of the important factors in understanding the willingness to move to work (intention to leave). The willingness to move work is emotionally generated from the experience of someone who is associated with the work that has long been formed. The unsatisfied employees are more likely to leave their jobs than those who are satisfied with their work. The same thing is also found in research conducted Manurung, that job satisfaction had a negatively effect on the employee turnover intention of Stikes Widya Husada Semarang [23]. Another reasearch that found the same thing done by Waspodo et al, the job satisfaction had a significant negative effect on turnover intention on employees of PT Unitex Bogor [24].

Besides seeing the direct effects of each of the independent variables on the dependent variables and intervening variables, this research also wants to see the indirect effects of job satisfaction, which is felt to correlate with previous researches, namely the effects of the interpersonal relationships to intention to leave through the job satisfaction as a mediation variable. And the effects of the role ambiguity on intention to leave through the job satisfaction as a mediation variable.

From the above description, then developed the proposed model of theoretical research as shown in the following figure:

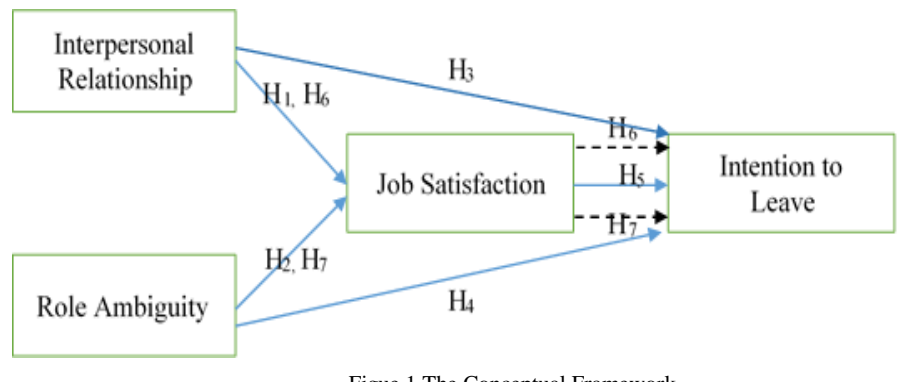

Figue 1 The Conceptual Framework

With reference to the conceptual framework of the research, hence the hypothesis in this research formulated as follows:

H1: The Interpersonal relationships have a positive and significant effect on job satisfaction of the event organizer employee.

$\mathrm{H}_{2}$ : The Role ambiguity has a negative and significant effect on job satisfaction of the event organizer employee.

H3: The Interpersonal relationships have a negative and significant effect on the intention to leave of the event organizer employee.

H4: The Role ambiguity has a positive and significant effect on the intention to leave of the event organizer employee.

H5: The job satisfaction has a negative and significant effect on the willingness to move (intention to leave) of the event organize employee.

H6: The Interpersonal relationships have a negative and significant effect on the intention to leave through the job satisfaction.

H7: The Role ambiguity has a positive and significant effect on the intention to leave through the job satisfaction. 


\section{THE RESEARCH METHODS}

\section{A. Time and Place of the Research}

The research was conducted for approximately 4 months from December 2016 to March 2017. The research was conducted in Medan City, North Sumatra, Indonesia..

\section{B. The Research Sample}

The research sample was 63 employees of EO companies who worked as project officer from 7 different EO companies in Medan city.

\section{The Collecting Data Methods}

The data used in this research were the primary data and the secondary data. The Primary data obtained in this research was respondents' perception data on the interpersonal relationship variables, the role ambiguity, the job satisfaction and the intention to leave. While the secondary data include biodata and data the number of the employees of the event organizer company in Medan City.

\section{The Collecting Data Methods}

The data used in this research were the primary data and the secondary data. The Primary data obtained in this research was respondents' perception data by using questionnaire that contains question on the interpersonal relationship variables, the role ambiguity, the job satisfaction and the intention to leave. While the secondary data include biodata and data the number of the employees of the event organizer company in Medan City.

\section{E. Data Analysis Methods}

Data analysis used the Structural Equation Model using PLS 3.0.

\section{THE RESEARCH RESUlT}

\section{A. The Respondent Characteristics}

The respondents caracteristics is described with the aim of seeing the distribution or general characteristics of the respondents in this research. The respondents caracteristics were divided by sex, age range, last education, majoring and duration of work.

\section{B. The Descriptive Statistics Analysis Result}

Headings, The Descriptive statistics in the research provide an overview of respondents' answers on each item of questions and statements submitted in research instruments. Therefore, this descriptive statistical analysis describes the perceptual image occurring in the sample and not to generalize in other circumstances. The statistical analysis results are summarized in table 1 below:

\begin{tabular}{|l|c|l|}
\hline Variables & $\begin{array}{c}\text { Grand } \\
\text { mean }\end{array}$ & Categories \\
\hline $\begin{array}{l}\text { The Interpersonal } \\
\text { relationships }\end{array}$ & 4,02 & Agree \\
\hline
\end{tabular}

\begin{tabular}{|l|c|l|}
\hline The Role Ambiguity & 2,86 & Less Agree \\
\hline Intention to Leave & 3,30 & Less Agree \\
\hline The Job Satisfaction & 3,82 & Agree \\
\hline
\end{tabular}

\section{Interpersonal Relationship}

The data processing results of statements regarding the interpersonal relationships obtained from 63 respondents showed that on average EO employees have good interpersonal relationships, in terms of relationships to superiors and relationships between colleagues. The average result from the interpersonal relationship was 4.02, included in the "agree" category.

\section{Role Ambiguity}

The average value of the role ambiguity of the EO companies employees amounted to 2.86 falling under the 'disagree' category, indicating that the roles ambiguity in EO companies were still at a middle level, or in other words the role ambiguity already exists, but only on the role aspect, namely the unclearness of the division of tasks only, where there was often incompatibility between job description and tasks assigned, the average score from each item statement spread from disagree, less agree to agree.

\section{Intention to Leave}

The Average answers every item statement about Intention to leave of the EO employees worth 3.30 which means it is in the category "less agree". This indicates that the employees already have a willingness to move but have not been followed by the real actions, such as trying to find a new job and will resign in the near future. The statement about intention to leave the majority of the answers in the category 'less agree' and a statement with the results agree.

\section{Job Satisfaction}

The job satisfaction of the EO employees were categorized as 'agree' or if correlated with the measured variable can be said to be 'good' with the average overall value is 3.82. All average scores result from each of the statements in the 'agree' category. This indicates that in general the job satisfaction of the employees who work at EO company in good condition.

\section{The Hypothesis Testing}

The hypothesis was tested statistically using the bootstrap method on SmartPLS. The bootstrap method was used to calculate the significance of the coefficient path obtained in the inner model. If the t-value is greater than the 1-way test $\mathrm{t}$ table with $5 \%$ significance, then the hypothesis was accepted. The result of path coefficient and significance of path coefficient are presented in Figure 2. 


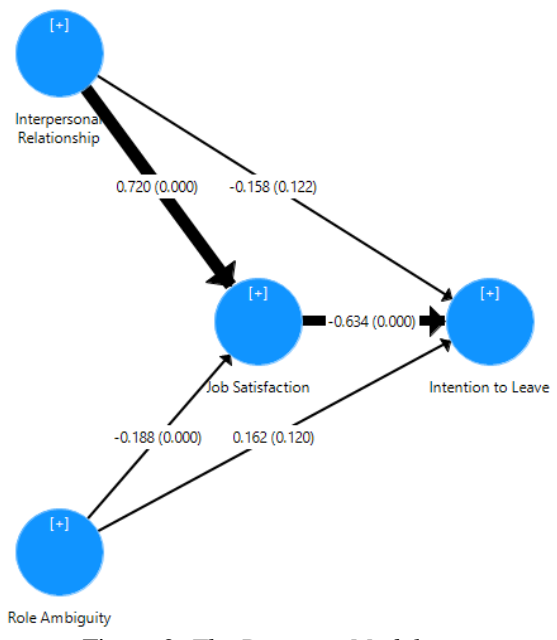

Figure 2. The Bootsrap Model

The effect of the Interpersonal Relationships on the Job Satisfaction of the Event Organizer Employees.

The Interpersonal relationships based on the results of this research have a positive and significant effect on the job satisfaction of the EO employees (path coefficient $=0.720 ; \mathrm{p}$ value $=0.000$ ). The results from this research were in line with Erdogan \& Enders findings, Lin \& Jennifer and Lee et al, who stated that the interpersonal relationships affect the job satisfaction. The better one's interpersonal relationship with the superiors or the leaders and among the colleagues will be the higher their job satisfaction.

\section{The effect of the Role Ambiguity on the Job Satisfaction of} the Event Organizer Employees.

The Role ambiguity gave a negative and significant effect on the job satisfaction of the event organizer employees, from the results of processing known that the coefficient of the path $=-0.188 ; \mathrm{p}$-value $=0,000$. The research results support other researchers where the higher the ambiguity of a person's role at work, then the lower the job satisfaction is felt $[25,26]$. Sulistiyawati stated that the role vagueness is a factor that can cause work stress because it can prevent an employee to perform its duties, which may lead to job dissatisfaction.

The effect of the Interpersonal Relationships on the Intention to Leave of the Event Organizer Employees.

The direct interpersonal relationship had a negative but not significant effect on the intention to leave of the event organizer employees (indirect effect $=-0.158$; $\mathrm{p}$-value $=$ $0.124)$. The Interpersonal relationships in this research proved unable to provide a significant effect in reducing the employee's intention to leave of the company. Although the descriptive results show that the interpersonal relationships between the superiors and among the colleagues work well but the employees prefer to leave the company if they have a chance to find another job, whether it's in another place or field.
The effect of the Role Ambiguity on the Intention to Leave of the Event Organizer Employees.

The role ambiguity directly gave positive influence but not significant to the intention to leave of the event organizer employee (indirect effect $=0,162 ; \mathrm{p}$-value $=0,108$ ). This research results were in line with the research conducted by Glissmeyer et al and Irzani where in his research there was no significant direct effect between the role ambiguity on employee's intention to leave.

The effect of the Job Satisfaction on the Intention to Leave of the Event Organizer Employees.

The job satisfaction directly gave a negative and significant effect to the intention to leave of the event organizer employee (indirect effect $=-0,634$; -value $=0,000$ ). This research results were in line with research conducted by Sihombing and Yaqin, which all of his research findings argue that the job satisfaction negatively affects the employees' intention to leave $[27,28]$. If the employee's job satisfaction is high, it will lower the intention to leave the company caused by job dissatisfaction and strive to survive and stay on the company.

\section{The effect of the Intention to Leave through the Job} Satisfaction

The Job satisfaction mediated the effect between the interpersonal relationships on intent to go perceived by the employees of the EO companies (indirect effect $=-0.457$; value $=0,000$ ). Reich and Sandy suggested that high levels of job dissatisfaction, a desire to move to work, and poor physical and mental health among the employees stem from poor the interpersonal relationships [29].

The interpersonal relationships directly have no significant effect on the intention to leave, but the interpersonal relationships negatively and significantly effect through the job satisfaction towards the intention to leave, meaning that the good interpersonal relationships will reduce the intention to leave if the interpersonal relationship leads to the job satisfaction and the opposite. In this case, the employee job satisfaction is a partial moderator on the effect of the interpersonal relationships to the intention to leave of the EO employees. In the VAF calculation, the indirect effect gave $74.30 \%$ of the total influence of the interpersonal relationship on the employee's intention to leave.

\section{The effect of the Role Ambiguity on the Intention to Leave} through the Job Satisfaction

The Job satisfaction mediates the effect of the role ambiguity on intention to leave perceived by employees of the EO companies (indirect effect 0.120; p-value $=0,000$ ). Fatima suggested that the employees facing the role ambiguity issues and role conflict will have an effect on the employee's performance and the job satisfaction.

The Role ambiguity has a positive but insignificant effect on the intention to leave, while indirectly negatively and significantly affects to the intention to leave, which means that a high role ambiguity will increase the intention to leave if the 
role ambiguity leads to the job dissatisfaction and the contrary. In this case, the employee's job satisfaction is a partial moderator on the effect of role ambiguity on the intention to leave of the EO employees. In the VAF calculation, the indirect effect gave $42.55 \%$ of the total impact of the role ambiguity on the employee's intention to leave.

\section{Discussion}

The physical work environment concerns the facility and the state of the work space, while the non-physical work environment concerns the interpersonal relationship of employees. The physical work environment can be enhanced through a shared concern for workplace conditions and environments. As for the non-physical work environment is also required a common awareness in building and fostering a good working relationship, to superiors and with colleagues colleagues. The Event organizers who rely on teamwork are in need of the good interpersonal relationships, not just cooperate but more to "get along" the sense of belonging, mutual respect. If it can be done then the problem of role ambiguity can be minimized, because of the mutual support among employees, among employees will try to help and fill the job vacancy. To create those feelings, it is better for the EO companies to have the policies, such as the incentive trips together once a year, the outbound activities, the employee gatherings, and other activities that can help to strengthen work teams.

The companies leaders as the policy makers and supervision should be able to ensure the employee's satisfaction in order to accommodate the desire for the company. In this research that led to the job dissatisfaction derived from the role ambiguity, where the employees often feel that the work they do not fit with job description, the circumstances like this most often occur when organizing the event. As a company leader of course this problem can be overcome by creating a good communication between the leadership and the employees who are given the task. The division of tasks should be equitable and clear, and if it is not possible because of the lack of manpower, then it is advisable to employ freelancers during the event to reduce the excessive workload on the employees.

The intention to leave the company in this research was measured using variables that were considered to have a direct effect as well as through the mediating variables on the intention to leave the company. The Intention to leave was measured using two dimensions of the desire to get out of the company and look for job vacancies in other places that these two dimensions are further subdivided into four indicators. Based on the results of data processing, the descriptive statistics, the biggest aspect in explaining the intention to leave the company is the desire to get out of the company if have other job opportunities. Majority feel agreed to leave the company if there is other job opportunities either opportunity to work in other field or different place.

The next aspect that identifies the desire to leave the company (intention to leave) is activeness in looking for another job opportunities. An employee who actively seeks other job opportunities describes that the work he is doing is still lacking in one or more things based on the employee's judgment. Although the result is not in majority but this statement is considered to have a firmly high score in describing the intention to leave the company.

The next aspect is the employee's participation in following the other job recruitment. In this case means the employee has made it happen in the form of attitudes with his / her participation to attend test calls at the other workplace even though must take permission while working. The employee participation in following the work recruitment is certainly a way to get closer to the decision to get out of the company.

The last aspect that indicates outgoing desire is the intention to leave the company in the near future. This aspect gets a negative response that can be said, there is no preparation or desire in the near future employees to resign from his job as an event organizer employee.

\section{CONCLUSION AND SUGGESTION}

\section{A. Conclusion}

The research undertaken answers the entire research hypothesis with the following conclusions:

- The interpersonal relationships have a positive and significant effect on the job satisfaction of the event organizer employees.

- The role ambiguity has a negative and significant effect on the job satisfaction of the event organizer employees.

- The interpersonal relationships have a negative and significant effect on the intention to leave of the event organizer employees.

- The role ambiguity has a positive and unsignificant effect on the intention to leave of the event organizer employees.

- The Job satisfaction has a negative and significant on intention to leave of the event organizer employees.

- The interpersonal relationships have a negative and significant indirect effect on the intention to leave of the event organizer employees through the job satisfaction.

- The role ambiguity has a positive and significant indirect effect on the intention to leave of the event organizer employees through the job satisfaction.

\section{B. Suggestion}

Suggestions that can be given are among others to the EO companies, the need to give the attention and guidance to each employee about his work, and to ensure the employees are satisfied with both their work and work environment. In addition, for the future research, in order to expand the researches that have been done both in terms of scale of the research and the variables researched, such as incorporating 
the effect of career development, job pressure on the satisfaction and its effect on intention to leave.

\section{References}

[1] A.A. Toly, "analysis of factors affecting turnover intentions at staff of public accounting firm". Jurnal Akuntansi \& Keuangan. Vol. 3(2), pp. 102-105. 2001.

[2] Sulistyawati, A. Ika, S.A. Rahmawati, and H.S. Lestari, "Organisasional, Konflik Peran, Ketidakjelasan Peran terhadap Kepuasan Kerja dan Keinginan Berpindah Kerja Auditor". 3rd Econmics \& Business Research Festival. Pp. 1427-1440. 2014.

[3] M. Herfitriani, "Pengaruh Kepuasan Kerja dan Komitmen Karyawan pada Organisasi terhadap Turnover Intention Karyawan pada PT. Biro Klasifikasi Indonesia Batam". Minithesis Faculty of Economic and Business University Sumatera Utara. 2016.

[4] K. Grant, D.W. Cravens, G.S. Low and W.C. Moncrief, "The role of satisfaction with territory design on the motivation, attitudes, and work outcomes os sales people", Journal of The Academy of Marketing Science. Vol 29(2), pp. 165-178. 2001

[5] Vemmylia, "Pengaruh Hubungan Interpersonal dan Lingkungan Kerja terhadap Kepuasan Kerja Karyawan Pada PT. PLN Cabang Binjai". Minithesis Universitas Sumatera Utara. 2009.

[6] S.P. Robbins, and T.A. Judge, "Organizational behavior fifteenth edition”. New York: Pearson Prentice Hall. Ebook. 2013.

[7] F. Luthans, "Perilaku Organisasi". 10th ed. Yogyakarta: Andi Publisher. 2006.

[8] S.P. Robbins, "Perilaku Organisasi". Jakarta: Prentice Hall. 2003.

[9] U. Nimran," "Perilaku organisasi”. Surabaya: CV. Citra Media. 2004.

[10] T. Melani, and Suhaji, "Faktor-faktor yang Mempengaruhi Kepuasan Kerja (Studi pada Karyawan Sekolah Tinggi Ilmu Farmasi 'Yayasan Pharmasi' Semarang”. Vol. 1(1), pp. 1-22. 2012

[11] M. Arni, "Komunikasi organisasi". Jakarta: Bumi Aksara. 2000.

[12] B. Erdogan, and J. Enders, "support from the top: supervisors' perceived organizational support as a moderator of leader-member exchange to satisfaction and performance relationships" Journal of Applied Psychology Vol. 92(2), pp. 321-330. 2007.

[13] S.C. Lin, and J.S.J. Lin, "Impact of coworkers' relationships on organizational commitment and intervening effect of job satisfaction". African Journal of Business Management. Vol. 5(8), pp. 3396-3409. 2011.

[14] C.C. Lee, S.H. Huang and Y.Z. Chen, "A study on factor affecting turnover intention of hotel employees". Asian Economic Financial Review. Vol. 2(7) pp. 866-875. 2012.

[15] A. Ketaren, Pengaruh Ambiguitas Peran dan Kepuasan Kerja terhadap Kinerja Karyawan PT. Suzuki Finance Indonesia Cabang Tebing Tinggi”. Jurnal Ilmiah Bussiness Progress. Vol. 3(1), pp. 1-8. 2015.

[16] I.S.N. Rohmawati, "Pengaruh Ambiguitas Peran terhadap Kepuasan Kerja Karyawan dengan Stres Kerja sebagai Variabel Mediasi pada PT. Waskita Beton Precast Plant Sidoarjo". Journal of Management Sciences Universitas Negeri Surabaya, Vol. 4(3), pp. 1-11. 2016.
[17] M.J. Tews,, J.W. Michel, and J.E. Ellingson, "The impact of coworker support on employee turnover in the hospitality industry". Group \& Organization Management 38, pp. 630-653. 2013.

[18] K.W. Mossholder, R.P. Settoon, and S.C. Henagan, "A relational perspective on turnover: examining structural, attitudinal, and behavioral predictors". Academy of Management Journal, Vol. 48, pp: 607-618. 2005.

[19] G. Regts, and E. Molleman, "To leave or not to leave: when receiving interpersonal citizenship behavior influences an empeloyee's turnover intention. Human Relation SAGE Journal. Vol. 66(2) pp. 193-218. 2013.

[20] D. Cahyono, "Persepsi Ketidakpastian Lingkungan, Ambiguitas Peran dan Konflik Peran sebagai Mediasi antara Program Mentoring dengan Kepuasan Kerja, Prestasi Kerja dan Niat Ingin Pindah Studi Empiris di Lingkungan Kantor Akuntan Publik (Kap) Besar". .Diponegoro university dissertation. 2007.

[21] M. Glissmeyer, J.W. Bishop, and R.D. Fass, "Role conflict, role ambiguity, and intention to quit the organization: the case og law enforcement officer". SWDSI Proceeding, pp. 458-469. 2007.

[22] D. Irzani, and A.D. Witjaksono, "Pengaruh Konflik Peran dan Ambiguitas Peran terhadap Keinginan Keluar Karyawan dengan Kepuasan Kerja Sebagai Variabel Mediasi pada PT. Asuransi Raksa Pratikara di Surabaya". Jurnal Ilmu Manajemen (JIM). Vol. 2(1), pp. 266-281. 2014.

[23] M.T. Manurung, and I. Ratnawati, "Analisis pengaruh stres kerja dan kepuasan kerja terhadap turnover intention karyawan (studi pada STIKES Widya Husada Semarang)". Diponegoro Jurnal of Management. Vol. 1(2), pp. 145-157. 2012.

[24] A.A.W.S. Waspodo, N.C. Handayani, and W. Paramita, “"Pengaruh Kepuasan Kerja dan Stres Kerja Terhadap Turnover Intention pada Karyawan PT Unitex di Bogor". Jurnal Riset Manajemen Sains Indonesia (JRSMI). Vol. 4(1) pp. 97-115. 2013.

[25] G. Fatima and W. Rehman, "Impact of role (ambiguity and conflict) on teaching assistants' satisfaction and intention to leave: Pakistan HEIs". International Journal of Business and Management. Vol. 7(16), pp. 5661. 2012.

[26] L. Agustina, "Pengaruh Konflik Peran, Ketidakjelasan Peran, dan Kelebihan Peran terhadap Kepuasan Kerja dan Kinerja Auditor (Penelitian pada Kantor Akuntan Publik yang Bermitra dengan Kantor Akuntan Publik Big Four di Wilayah DKI Jakarta)". Accounting journal. 2009. Vol. 1(1) pp. 40-69.

[27] A. Sihombing, and S. Saragih, "Pengaruh Kepuasan Kerja Karyawan Terhadap Turnover Intention dengan Withdrawal Cognition dan Job Search Sebagai Variabel Pemediasi”. Business and Management Review Universitas Kristen Maranatha. pp. 305-320. 2012

[28] M.A. Yaqin, "Pengaruh Kepuasan Kerja dan Komitmen Organisasi Terhadap Turnover Intention Karyawan KJPP Toha, Okky, Heru \& Rekan Cabang Surabaya”. Jurnal Ilmu Manajemen (JIM) Vol. 1(2), pp. 919-930. 2013.

[29] T. Reich, and S. Hershcovis, "Interpersonal relationship at work". Handbook of industrial and organizational pshychology, Vol. 3, pp. 223248. 2011. 